\title{
Association between vitamin D deficiency and mortality in critically ill adult patients: a meta-analysis of cohort studies
}

\author{
Yan-Peng Zhang ${ }^{1 \dagger}$, You-Dong Wan ${ }^{1 \dagger}$, Tong-Wen Sun ${ }^{1 *}$, Quan-Cheng Kan ${ }^{2^{*}}$ and Le-Xin Wang ${ }^{3^{*}}$
}

\begin{abstract}
Introduction: Vitamin D deficiency is common in critically ill patients, and was reported to be associated with adverse outcomes. However, the effect of vitamin D deficiency on mortality in critically ill patients remains unclear.

Methods: We searched PubMed and EMBASE from the inception to July 2014 for cohort studies to assess the effect of vitamin D deficiency on the incidence of mortality in critically ill patients. Mortality-specific odds ratio (OR) with 95\% confidence interval $(\mathrm{Cl})$ were pooled with a random- or fixed-effect models when appropriate.

Results: Seven cohort studies with a total of 4,204 participants including 1,679 cases of vitamin D deficiency were included in this meta-analysis. Vitamin D deficiency was significantly associated with an increased hospital mortality (OR 1.76; 95\% Cl, 1.38 to $2.24 ; P<0.001)$, with very low heterogeneity $\left(I^{2}=2.3 \% ; P=0.402\right)$. The finding of increased hospital mortality in critically ill adult patients was consistently found in every stratum of our subgroup analyses.
\end{abstract}

Conclusions: This meta-analysis suggests that vitamin D deficiency is associated with increased incidence of hospital mortality in critically ill adult patients.

\section{Introduction}

Vitamin D is a group of fat-soluble vitamins that play a significant role in the regulation of bone metabolism [1], it also plays a major role in extra-skeletal metabolic processes, such as glucose metabolism, and in many aspects of cellular functions [2,3]. Vitamin D deficiency is associated with various disorders such as diabetes, infections, myocardial infarction, autoimmune disease, chronic obstructive pulmonary disease, tuberculosis, and excess mortality in the general population [4]. The incidence of vitamin $\mathrm{D}$ deficiency has been reported to range from $26 \%$ to $82 \%$ in critically ill patients $[5,6]$, and mounting evidence indicates that vitamin D deficiency is associated with adverse outcomes such as increased infection rates,

\footnotetext{
* Correspondence: suntongwen@163.com; 1017361289@qq.com; LWang@csu.edu.au

${ }^{\dagger}$ Equal contributors

'Department of Integrated Intensive Care Unit, the First Affiliated Hospital, Zhengzhou University, 1 Jianshe East Road, Zhengzhou 450052, China

${ }^{2}$ Pharmaceutical Department, the First Affiliated Hospital, Zhengzhou University, 1 Jianshe East Road, Zhengzhou 450052, China

${ }^{3}$ School of Biomedical Science, Charles Sturt University, Wagga Wagga, NSW 2650, Australia
}

\section{Biomed Central}

(c) 2014 Zhang et al.; licensee BioMed Central. This is an Open Access article distributed under the terms of the Creative Commons Attribution License (http://creativecommons.org/licenses/by/4.0), which permits unrestricted use, distribution, and reproduction in any medium, provided the original work is properly credited. The Creative Commons Public Domain Dedication waiver (http://creativecommons.org/publicdomain/zero/1.0/) applies to the data made available in this article unless otherwise stated. prolonged length of ICU stay [7], higher in-hospital mortality [8], and increased health care costs [9]. However, Ralph et al. [10] did not observe an association between low levels of vitamin D and increased risk of mortality in critically ill patients, but they did find that patients with above physiological vitamin D levels had higher mortality and illness severity scores.

At present, the effect of vitamin D deficiency on outcomes such as mortality and morbidity in critically ill patients is not clear. We conducted a meta-analysis of seven cohort studies to investigate the effect of vitamin D deficiency on clinical outcomes such as hospital mortality, ICU mortality and length of ICU stay in critically ill adult patients.

\section{Materials and methods \\ Search strategy}

The search was carried out in keeping with the statement of meta-analysis of observational studies in epidemiology (MOOSE) [11]. Without language restrictions, the literature from the inception to July 2014 was searched in PubMed and EMBASE. The following search terms were used: 'Vitamin D', 'cholecalciferol', 'hydroxycholecalciferols', 
'ergocalciferol', '25-hydroxyvitamin $\mathrm{D}_{2}$ ', 'dihydrotachysterol', 'critical ill' and 'critically ill'. Furthermore, we reviewed the reference lists in the retrieved articles and recent reviews to identify other potential relevant studies.

\section{Study selection}

A published study was included if it: 1) was a cohort design; 2) explored the effect of vitamin D deficiency on mortality in the critically ill adult patients; 3) reported the adjusted effect size and its 95\% CI. In the case of duplicate publication, we only included studies that were the most informative and complete.

\section{Data extraction and quality assessment}

The following information was abstracted from all the included studies by using a standardized data collection form: study name (together with the first author's name and publication year), study design, country, population characteristics, number of patients, number of vitamin D deficiency cases, gender composition in patients, mean age of the patients, severity of illness by simplified acute physiology score (SAPS) or acute physiology and chronic health evaluation (APACHE) score, definition of vitamin D deficiency, major clinical outcomes, and quantity score. We also checked the supplementary files, and contacted the authors for more detailed information where necessary.

We assessed the authenticity and quality of the included studies by Newcastle-Ottawa scales (NOS) [12], in which a study was judged on three broad perspectives consisting of eight items. We assigned risk-of-bias categories in accordance with the number of adequate items of NOS that were judged in each study: assessing the following categories: low risk of bias (six to eigt adequate items), medium risk of bias (four to five adequate items), high risk of bias (fewer than four adequate items), very high risk of bias (no description of methods). Two investigators (YP Zhang and YD Wan) carried out the literature search, study selection, data extraction and quality assessment independently. Any discrepancies were resolved by consensus.

\section{Statistical analysis}

To compute a summary odds ratio (OR), we used the adjusted OR and its 95\% CI in all analyses. The hazard ratio (HR) was considered as the OR directly. The heterogeneity test was conducted using the Cochran Q-statistic at the $P<0.10$ level of significance. We also quantified the $I^{2}$ statistic, which describes the inconsistency due to the heterogeneity across studies [13-15]. An $I^{2}$ value $>50 \%$ indicates significant heterogeneity. The appropriate pooling method was decided according to the value of the $I^{2}$ statistic: fixed-effects models for $I^{2}<50 \%$ and randomeffects models for $I^{2} \geq 50 \%$ [13-15]. Prespecified subgroup analyses were performed according to minimum serum 25-hydroxyvitamin D (25(OH)D) level as the threshold to define vitamin D deficiency $(20 \mathrm{ng} / \mathrm{ml}, 15 \mathrm{ng} / \mathrm{ml}, 12 \mathrm{ng} / \mathrm{ml}$, $10 \mathrm{ng} / \mathrm{ml}$ ) to examine the influence of this clinical factor on the overall risk estimation. We also conducted a sensitivity analysis by changing the pooling model (fixed-effects model or random-effects model) and using the one-studyout method and applying various exclusion criteria to test the robustness of the pooled estimate. Potential publication bias was assessed by the Egger linear regression test [16]. $P<0.05$ was considered to be representative of a significant statistical publication bias, except where otherwise specified. All statistical analyses were performed by using STATA, version 11.0 (Stata Corp).

\section{Results}

\section{Study selection and study characteristics}

Our initial search yielded 98 potentially relevant publications, 3 of which were excluded for duplicate publications. We excluded 62 studies based on title and abstract review. After reviewing the full text of the remaining 33 studies, we identified 7 cohort studies in this present meta-analysis [8,17-22]. The reasons for excluding studies in the final review included: reviews and editorial articles, small sample size $(\mathrm{n}<100)$, not relevant to our analysis, and studies not reporting adjusted ORs of risk estimates and the 95\% CI (see the detail in Figure 1).

The main characteristics of the seven studies included in this meta-analysis are shown in Table 1. In total, 4,204 participants including 1,679 cases of vitamin D deficiency were enrolled in this meta-analysis. The studydesign types were as follows: single-center studies $(n=4$ $[8,18,19,22])$, multicenter studies $(\mathrm{n}=3[17,20,21])$, retrospective studies $(\mathrm{n}=3[8,17,22])$, and prospective studies $(\mathrm{n}=4$ [18-21]). Six studies presented outcome of hospital mortality $[8,17,18,20-22]$, and only two studies presented outcome of ICU mortality [19,22]. As for length of ICU stay, one study provided data expressed as mean \pm SD [8], two studies did not report it $[17,20]$, and the remaining four described the data as median [18,19,21,22]. Every single study was matched or adjusted for a wide range of potential confounders. There is no consistent definition of vitamin D deficiency between included studies. The average NOS score of the included studies was 6.6 (range from 6 to 7). An additional table file shows this in more detail (Additional file 1).

\section{Overall results}

Combined by the fixed-effects model, the multivariableadjusted OR for hospital mortality and ICU mortality for each study is shown in Figures 2 and 3, respectively. Results from six studies showed that vitamin D deficiency is associated with an increased risk of hospital mortality 


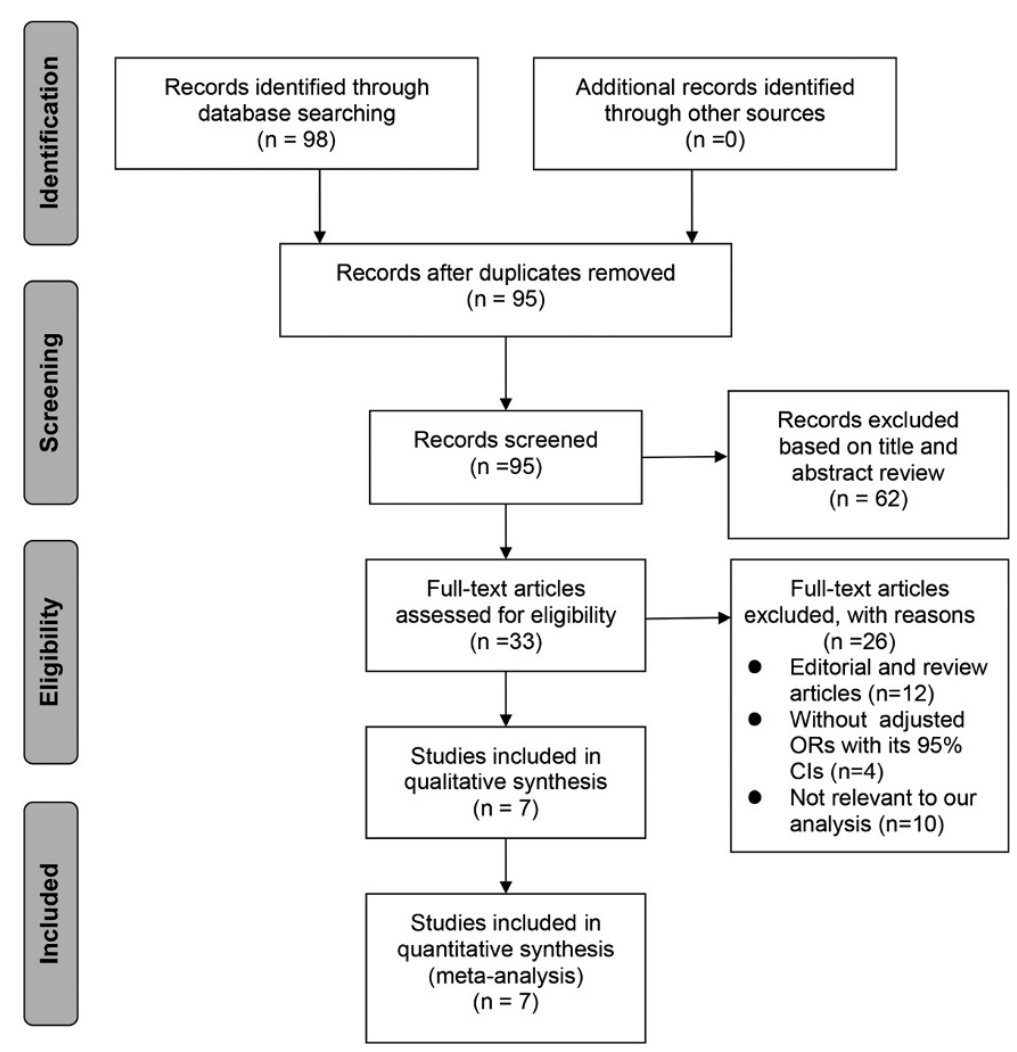

Figure 1 Flow chart of article selection. OR, odds ratio.

(OR 1.76; 95\% CI, 1.38, 2.24; $P<0$. 001), with very low heterogeneity among the studies $\left(I^{2}=2.3 \% ; P=0.402\right)$. For ICU mortality, there was not enough evidence to conclude that vitamin $\mathrm{D}$ deficiency was not associated with increased incidence of ICU mortality in critically ill adult patients (OR 1.43; 95\% CI, 0.76, 2.70; $P=0.271$ ). The data for length of ICU stay for every individual study are presented in Table 2 .

\section{Subgroup and sensitivity analyses}

Table 3 shows the results of subgroup and sensitivity analyses. Definition of vitamin D deficiency varies between studies, which may impact the overall estimates. We therefore stratified mortality rates across different studies based on vitamin D thresholds as a continuum, and the finding of increased incidence of hospital mortality in critically ill adult patients was consistently found in each stratum. Our sensitivity analyses suggested that the overall estimates were not materially altered by changing pooling models (fixed-effects model: OR 1.76; 95\% CI, 1.38, 2.24 and random-effects model: OR 1.76; 95\% CI, 1.37, 2.26), and also did not materially alter when any single study was removed in turn, with a range from $1.67(95 \% \mathrm{CI}, 1.30,2.15)$ to $1.82(95 \% \mathrm{CI}$, $1.42,2.34)$.

\section{Publication bias}

Publication bias was assessed, but the low power with only seven studies limited the interpretability of the finding.

\section{Discussion}

\section{Main findings}

To the best of our knowledge, this is the first metaanalysis to explore the effect of vitamin D deficiency on mortality in critically ill adult patients. This study suggests that vitamin D deficiency is associated with increased hospital mortality in critically ill adult patients. The effect of vitamin D deficiency was observed in every stratum of our subgroup analyses. In addition, a relatively small number of samples (only two studies $[19,22]$ ) provided data on ICU mortality, and the final estimate showed there was not enough evidence to conclude that vitamin D deficiency was not associated with increased incidence of ICU mortality in critically ill adult patients (OR 1.43; 95\% CI, 0.76, 2.70; $P=0.271$ ).

\section{Possible mechanism}

Although vitamin D deficiency may increase the incidence of hospital mortality in the critically ill adult patients, the reason remains unclear and can be explained by several different mechanisms. First, a range of biological 
Table 1 Main characteristics included in the meta-analysis

\begin{tabular}{|c|c|c|c|c|c|c|c|}
\hline $\begin{array}{l}\text { First author/Year } \\
\text { of publication } \\
\text { (reference) }\end{array}$ & Amrein et al./2014 [22] & Aygencel et al./2013 [19] & Hu et al./2013 [18] & Nair et al./2012 [21] & Higgins et al./2012 [20] & Venkatram et al./2011 [8] & Braun et al./2011 [17] \\
\hline Study design & $\begin{array}{l}\text { Single-center, } \\
\text { retrospective }\end{array}$ & Single-center, prospective & Single-center, prospective & Multi-center, prospective & Multi-center, prospective & Single-center, retrospective & $\begin{array}{l}\text { Multi-center, } \\
\text { retrospective }\end{array}$ \\
\hline Country & Austria & Turkey & China & Australia & Canada & USA & USA \\
\hline Patients & $\begin{array}{l}\text { Neurologic (30.2\%), } \\
\text { cardiac surgery (15.0\%), } \\
\text { respiratory disease } \\
(8.1 \%) \text {, trauma }(5.8 \%), \\
\text { brain surgery }(5.0 \%), \\
\text { infectious diseases, } \\
\text { including sepsis at } \\
\text { admission (4.4\%) }\end{array}$ & $\begin{array}{l}\text { Respiratory insufficiency } \\
(45 \%) \text {, organ dysfunctions } \\
(44 \%) \text {, invasive mechanical } \\
\text { ventilation (44\%), sepsis/ } \\
\text { septic shock }(35.8 \%) \text {, renal } \\
\text { replacement therapy (34\%), } \\
\text { nosocomial infection (35\%) }\end{array}$ & $\begin{array}{l}\text { Severe pneumonia with } \\
\text { respiratory failure (47.2\%), } \\
\text { acute exacerbations of } \\
\text { chronic obstructive } \\
\text { pulmonary disease }(19 \%) \text {, } \\
\text { intra-abdominal infection } \\
(15.3 \%) \text {, mechanical } \\
\text { ventilation (85.6\%) }\end{array}$ & $\begin{array}{l}\text { Cardiac (30\%), infection/ } \\
\text { sepsis }(26 \%) \text {, heart/lung/ } \\
\text { bone marrow transplant } \\
(21 \%) \text {, trauma (9\%), } \\
\text { metabolic }(7 \%), \\
\text { neurological }(7 \%)\end{array}$ & $\begin{array}{l}\text { Cardiovascular (14\%), } \\
\text { respiratory (29\%), } \\
\text { neurological }(7 \%), \\
\text { metabolic }(7 \%), \\
\text { gastrointestinal (3\%), } \\
\text { sepsis (5\%), postoperative } \\
(35 \%)\end{array}$ & $\begin{array}{l}\text { Cardiac }(4.8 \%) \text {, gastrointestinal } \\
(10.7 \%), \text { metabolic }(11.4 \%), \\
\text { neurological (12.5\%), } \\
\text { obstructive airway disease } \\
(13.7 \%), \text { pulmonary }(18.3 \%) \text {, } \\
\text { others }(10.9 \%) \text {, renal }(5 \%) \text {, } \\
\text { sepsis/septic shock }(12.3 \%)\end{array}$ & $\begin{array}{l}\text { Medical (58.3\%) } \\
\text { Surgical (41.7\%) }\end{array}$ \\
\hline Patients, $\mathbf{n}$ & 655 & 201 & 216 & 100 & 196 & 437 & 2,399 \\
\hline $\begin{array}{l}\text { Case patients, } \\
\text { n (\%) }\end{array}$ & $394(60.2 \%)$ & $139(69.2 \%)$ & 95 (44.0\%) & $24(24.0 \%)$ & $50(25.5 \%)$ & $340(77.8 \%)$ & $637(26.6 \%)$ \\
\hline $\begin{array}{l}\text { Male patients, } \\
\text { n (\%) }\end{array}$ & $412(62.9 \%)$ & $113(56.0 \%)$ & $120(55.6 \%)$ & $65(65.0 \%)$ & $121(62.0 \%)$ & $208(47.5 \%)$ & $1,030(43.0 \%)$ \\
\hline Age, $y$, mean & $65(22)^{a}$ & $66(21)^{\mathrm{a}}$ & $64(25)^{\mathrm{a}}$ & $52 \pm 17^{b}$ & $64 \pm 14^{b}$ & $56.6 \pm 17.1^{b}$ & $64.9 \pm 16.6^{b}$ \\
\hline $\begin{array}{l}\text { Severity of } \\
\text { illness }\end{array}$ & $26(16)^{a}$ (SAPS II) & $23(11)^{\mathrm{a}}$ (APACHE II) & $21(8)^{a}($ APACHE II) & $21 \pm 8^{\mathrm{b}}$ (APACHE II) & $20.2 \pm 7.8^{\mathrm{b}}($ APACHE II) & $67.0 \pm 27.5^{\mathrm{b}}$ (APACHE IV) & / \\
\hline $\begin{array}{l}\text { Definition of } \\
\text { Vitamin D } \\
\text { deficiency, } \\
\text { insufficiency } \\
\text { and sufficiency }\end{array}$ & $\begin{array}{l}\text { Deficient }(<20 \mathrm{ng} / \mathrm{ml}) \text {, } \\
\text { insufficient }(\geq 20 \\
\text { and }<30 \mathrm{ng} / \mathrm{ml}) \text {, } \\
\text { normal }(\geq 30 \mathrm{ng} / \mathrm{ml})\end{array}$ & $\begin{array}{l}\text { Insufficient (<20 ng/ml), } \\
\text { sufficient ( } \geq 20 \mathrm{ng} / \mathrm{ml})\end{array}$ & $\begin{array}{l}\text { Deficient }(<20 \mathrm{ng} / \mathrm{ml}) \text {, } \\
\text { insufficient }(\geq 20 \\
\text { and }<30 \mathrm{ng} / \mathrm{ml}) \text {, } \\
\text { sufficient }(\geq 30 \mathrm{ng} / \mathrm{ml})\end{array}$ & $\begin{array}{l}\text { Deficient }(<10 \mathrm{ng} / \mathrm{ml}) \text {, } \\
\text { insufficient }(10 \text { to } \\
20 \mathrm{ng} / \mathrm{ml}) \text {, sufficient } \\
(>20 \mathrm{ng} / \mathrm{ml})\end{array}$ & $\begin{array}{l}\text { Deficient }(\leq 12 \mathrm{ng} / \mathrm{ml}) \text {, } \\
\text { insufficient }(>12 \\
\text { to } \leq 24 \mathrm{ng} / \mathrm{ml}) \text {, sufficient } \\
\text { ( } 24 \mathrm{ng} / \mathrm{ml})\end{array}$ & $\begin{array}{l}\text { deficient }(<20 \mathrm{ng} / \mathrm{ml}) \text {, } \\
\text { insufficient }(\geq 20 \\
\text { and }<30 \mathrm{ng} / \mathrm{ml}) \text {, } \\
\text { sufficient }(\geq 30 \mathrm{ng} / \mathrm{ml})\end{array}$ & $\begin{array}{l}\text { deficient }(\leq 15 \mathrm{ng} / \mathrm{mL} \text {, } \\
\text { insufficient ( } 16 \text { to } \\
29 \mathrm{ng} / \mathrm{mL} \text {, sufficient } \\
(\geq 30 \mathrm{ng} / \mathrm{mL})\end{array}$ \\
\hline $\begin{array}{l}\text { Major clinical } \\
\text { outcomes }\end{array}$ & $\begin{array}{l}\text { ICU and hospital } \\
\text { mortality, ICU and } \\
\text { hospital LOS }\end{array}$ & ICU mortality & Hospital mortality & $\begin{array}{l}\text { Hospital mortality, ICU } \\
\text { and hospital LOS }\end{array}$ & $\begin{array}{l}\text { Hospital mortality, } \\
\text { time-to-alive ICU } \\
\text { discharge }\end{array}$ & $\begin{array}{l}\text { Hospital mortality, } \\
\text { hospital LOS }\end{array}$ & $\begin{array}{l}\text { 30-day, 90-day, } \\
\text { 365-day, and } \\
\text { in-hospital morality }\end{array}$ \\
\hline Quality score ${ }^{c}$ & 7 & 6 & 6 & 7 & 7 & 6 & 7 \\
\hline
\end{tabular}

${ }^{a}$ Median (interquartile range); ${ }^{b}$ mean \pm SD; ${ }^{c}$ Newcastle-Ottawa scales (NOS). SAPS, simplified acute physiology score; APACHE, acute physiology and chronic health evaluation; LOS, length of stay. 
responses involving immune system functions and processes in cellular growth, proliferation, and apoptosis may be influenced by vitamin $\mathrm{D}[1,23]$. Vitamin $\mathrm{D}$ regulates the expression of the antimicrobial peptides cathelicidin (LL-37) and $\beta$-defensin, both of which have functional effectors within the immune system [24,25]. Cathelicidin can fight against a broad spectrum of infectious agents, including Gram-negative and -positive bacteria, as well as fungi [24]. Second, as vitamin D is a known link between toll-like receptors (TLR) activation and innate immunity [26], and vitamin D receptors are expressed in T cells [27], activated B cells [28], and dendritic cells [29], vitamin D deficiency may increase the risk of inflammation and sepsis in the critically ill by the suppression of immune reactivity and stimulatory effects on innate immunity [30-32]. Third, vitamin $\mathrm{D}$ has also been found to downregulate proinflammatory cytokines such as interferon- $\gamma$, tumor necrosis factor- $\alpha$, and IL-1, IL-2, IL-6, IL-8, IL-12, as well as $\mathrm{T}$ helper 1 cells and $\mathrm{B}$ cells in the adaptive immune system $[33,34]$. At the same time, vitamin D upregulates anti-inflammatory cytokines, such as IL-4, IL-5 and IL-10. It promotes the expression of T-regulatory cells, which turn off the adaptive immune response [35]. These studies suggest that vitamin $\mathrm{D}$ deficiency disturb the innate immunity system and compromises the ability of critically ill patients to downregulate the adaptive immune response. In addition, the tissue requires more vitamin D in critically ill patients, and vitamin D deficiency may result in widespread tissue dysfunction [36]. These effects may explain why increasing mortality results from systemic inflammatory response syndrome, organ failure and metabolic dysfunction in critically ill patients.

\section{Clinical implications}

Our findings may have several implications. As vitamin D deficiency impacts on mortality in critically ill patients, vitamin D levels may be used to predict the outcomes in critically ill patients. Unlike markers such as C-reactive protein (CRP), procalcitonin, D-dimer and leucocyte counts, which have been shown to predict

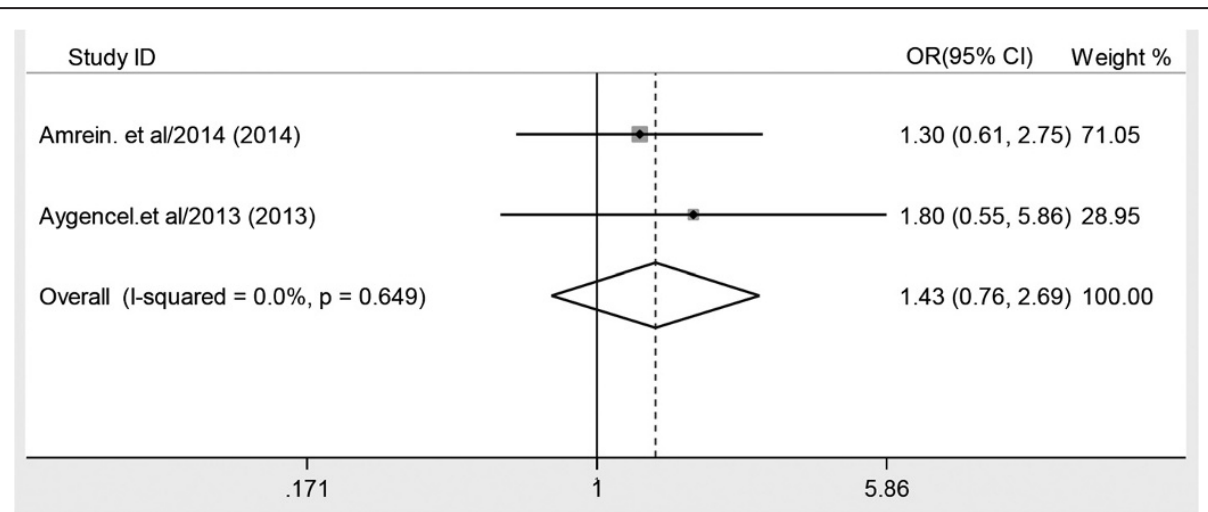

Figure 3 Forest plot showing the effect of vitamin D deficiency on ICU mortality. OR, odds ratio. 
Table 2 ICU length of stay among studies

\begin{tabular}{|c|c|c|c|}
\hline Study & Year & Vitamin D classification & $\begin{array}{l}\text { ICU length of } \\
\text { stay (days) }\end{array}$ \\
\hline \multirow[t]{3}{*}{ Amrein et al. [22] } & 2014 & Deficiency, $<20$ ng/ml & $6.9(9.8)^{a}$ \\
\hline & & insufficiency, 20 to $30 \mathrm{ng} / \mathrm{ml}$ & $4.9(7.7)^{\mathrm{a}}$ \\
\hline & & sufficiency, >30 ng/ml & $5.2(6.5)^{a}$ \\
\hline \multirow[t]{2}{*}{ Aygencel et al. [19] } & 2013 & Insufficiency, $<20 \mathrm{ng} / \mathrm{ml}$ & $9(5,14)^{b}$ \\
\hline & & sufficiency, $\geq 20$ ng/ml & $8(5,13)^{b}$ \\
\hline \multirow[t]{3}{*}{ Hu et al. [18] } & 2013 & Deficiency, $<20$ ng/ml & $10.5(6.8,25.3)^{b}$ \\
\hline & & insufficiency, 20 to $30 \mathrm{ng} / \mathrm{ml}$ & $8.6(6.9,20.5)^{b}$ \\
\hline & & sufficiency, $>30 \mathrm{ng} / \mathrm{ml}$ & $15.2(10.3,23.6)^{b}$ \\
\hline \multirow[t]{3}{*}{ Nair et al. [21] } & 2012 & Deficiency, $<10 \mathrm{ng} / \mathrm{ml}$ & $12(2,14)^{b}$ \\
\hline & & insufficiency, 10 to $20 \mathrm{ng} / \mathrm{ml}$ & $7(4,15)^{b}$ \\
\hline & & sufficiency, $>20 \mathrm{ng} / \mathrm{ml}$ & $4(3,10)^{b}$ \\
\hline \multirow[t]{3}{*}{ Higgins et al. [20] } & 2012 & Deficient, $\leq 12 \mathrm{ng} / \mathrm{ml}$ & $10.6 \pm 8.4^{c}$ \\
\hline & & insufficient, 12 to $24 \mathrm{ng} / \mathrm{ml}$ & $6.8 \pm 6.0^{c}$ \\
\hline & & sufficient, > $24 \mathrm{ng} / \mathrm{ml}$ & $5.9 \pm 5.4^{c}$ \\
\hline \multirow[t]{3}{*}{ Venkatram et al. [8] } & 2011 & Deficiency, $<20$ ng/ml & $4.3 \pm 4.5^{c}$ \\
\hline & & insufficiency, 20 to $30 \mathrm{ng} / \mathrm{ml}$ & $3.7 \pm 3.9^{c}$ \\
\hline & & sufficiency, $>30$ ng/ml & $4.2 \pm 3.7^{c}$ \\
\hline Braun et al. [17] & 2011 & - & - \\
\hline
\end{tabular}

${ }^{\mathrm{a}}$ Median (interquartile range); ${ }^{\mathrm{b}}$ median $(\mathrm{Q} 1, \mathrm{Q} 3){ }^{\mathrm{c}}{ }^{\mathrm{m}}$ ean $\pm \mathrm{SD}$.

disease severity in critically ill patients [37], vitamin D levels may not only predict disease severity and outcomes but also contribute to the comorbidities commonly seen in critically illness. Our meta-analysis may offer possibilities for therapeutic exploitation of vitamin D supplementation in critical illness. A recent randomized clinical trial by Amrein and colleagues [38] suggested that administration of high-dose vitamin $\mathrm{D}_{3}$ compared with placebo did not improve hospital length of stay and hospital mortality for vitamin D-deficient $(\leq 20 \mathrm{ng} / \mathrm{mL})$ patients who are critically ill. However, lower hospital mortality was observed in a subgroup of patients with severe vitamin $D$ deficiency $(\leq 12 \mathrm{ng} / \mathrm{mL})$ [38]. These findings should be interpreted with caution and researchers should probe further into the effect of vitamin D supplementation on adverse outcomes, as well as the assessment of its dosing efficacy and safety.

\section{Strengths and limitations}

The generalizability of our meta-analysis has been enhanced by its exhaustive search without language restrictions and by using the MOOSE guidelines as our systematic review methods. Also, we are able to enhance the precision of the risk estimates with our strict inclusive criteria. We included seven cohort studies with high quality, which minimized the likelihood of recall interviewer and selection biases that can be a concern in epidemiological studies. We did not find any
Table 3 Subgroup and sensitivity analyses for hospital mortality

\begin{tabular}{|c|c|c|c|c|}
\hline Analyses & Studies, $\mathbf{n}$ & $\begin{array}{l}\text { Odds ratio } \\
(95 \% \mathrm{Cl})\end{array}$ & $P_{\text {heterogeneity }}$ & $1^{2}$ \\
\hline \multicolumn{5}{|l|}{ Subgroup analysis } \\
\hline Total $[8,17-22]$ & 7 & $1.76(1.38,2.24)$ & 0.402 & $2.3 \%$ \\
\hline \multicolumn{5}{|l|}{$\begin{array}{l}25(\mathrm{OH}) \mathrm{D} \text { level as a } \\
\text { cutoff for vitamin } \mathrm{D} \\
\text { deficiency }\end{array}$} \\
\hline $20 \mathrm{ng} / \mathrm{ml}[8,18,22]$ & 3 & $2.12(1.35,3.34)$ & 0.198 & $38.3 \%$ \\
\hline 15 ng/ml [17] & 1 & $1.72(1.27,2.33)$ & - & - \\
\hline 12 ng/ml [20] & 1 & $1.12(0.45,2.70)$ & - & - \\
\hline $10 \mathrm{ng} / \mathrm{ml}[21]$ & 1 & $1.13(0.18,7.27)$ & - & - \\
\hline \multicolumn{5}{|l|}{ Sensitivity analysis } \\
\hline Multicenter $[17,20,21]$ & 3 & $1.63(1.23,2.17)$ & 0.623 & $0.0 \%$ \\
\hline $\begin{array}{l}\text { Prospective cohort } \\
{[18,20,21]}\end{array}$ & 3 & $1.83(1.03,3.24)$ & 0.241 & $29.7 \%$ \\
\hline \multicolumn{5}{|l|}{ One-study-out method } \\
\hline Amrein [22] & 1 & $1.79(1.23,2.70)$ & 0.284 & $20.5 \%$ \\
\hline $\mathrm{Hu}[18]$ & 1 & $1.67(1.30,2.15)$ & 0.511 & $0.0 \%$ \\
\hline Nair [21] & 1 & $1.77(1.39,2.26)$ & 0.298 & $18.3 \%$ \\
\hline Higgins [20] & 1 & $1.82(1.42,2.34)$ & 0.396 & $1.8 \%$ \\
\hline Venkatram [8] & 1 & $1.72(1.35,2.19)$ & 0.571 & $0.0 \%$ \\
\hline Braun [17] & 1 & $1.82(1.23,2.70)$ & 0.281 & $21.0 \%$ \\
\hline \multicolumn{5}{|l|}{$\begin{array}{l}\text { Fixed-effects versus } \\
\text { random-effects model } \\
\text { method }\end{array}$} \\
\hline Fixed-effects model & 6 & $1.76(1.38,2.24)$ & 0.402 & $2.3 \%$ \\
\hline Random-effects model & 6 & $1.76(1.37,2.26)$ & 0.402 & $2.3 \%$ \\
\hline
\end{tabular}

25(OH)D, 25-hydroxyvitamin D.

significant heterogeneity between the studies included in our meta-analysis.

Several limitations should be acknowledged. First, some studies in this analysis did not utilize liquid chromatography-tandem mass spectrometry (LC-MS/MS) to determine $25(\mathrm{OH})$ D levels [39], which may potentially impact on the overall results. Second, vitamin D levels have seasonal variations, which have the highest mean values in August and the lowest mean levels in March [22]. Only the study by Amrein and colleagues [22] took seasonal influence into account, so we could not adjust this factor. Third, most studies were conducted in some specific ICUs, such as surgical ICU or medical ICU, which may not represent all ICU patients. Fourth, the definition of vitamin D deficiency in critically ill patients remains inconsistent, and in our meta-analysis, different criteria of vitamin $\mathrm{D}$ definition was used among the studies.

\section{Conclusions}

This study showed that vitamin D deficiency is associated with increased hospital mortality in critically ill 
adult patients. However, there is not enough evidence to conclude that vitamin $\mathrm{D}$ deficiency is not associated with increased ICU mortality in critically ill adult patients, which requires more studies to probe this issue further in the future.

\section{Key messages}

- Vitamin D deficiency is associated with increased incidence of hospital mortality in critically ill adult patients

- Current evidence about vitamin D deficiency and increased ICU mortality is still not sufficient to draw a firm conclusion

- More studies should probe further into the effect on ICU mortality in critically ill adult patients

\section{Additional file}

Additional file 1: Methodological quality assessment (risk of bias) of included studies by Newcastle-Ottawa scales.

\section{Abbreviations}

25(OH)D: 25-hydroxyvitamin D; APACHE: acute physiology and chronic health evaluation; CRP: C-reactive protein; HR: hazard ratio; IL: interleukin; LC-MS/ MS: liquid chromatography-tandem mass spectrometry; LOS: length of stay; MOOSE: meta-analysis of observational studies in epidemiology; NOS: NewcastleOttawa scales; OR: odds ratio; SAPS: simplified acute physiology score; TLR: tolllike receptors.

\section{Competing interests}

The authors declare that they have no competing interests.

\section{Authors' contributions}

YPZ conceived the study, participated in the design, collected the data, and drafted the manuscript. YDW collected the data, and performed statistical analyses. KQC helped to collect the data. YDW and TWS conceived the study, participated in the design, and helped to draft the manuscript. LXW edited and checked the manuscript. All authors read and approved the final manuscript.

\section{Acknowledgements}

This study was supported by the National Natural Science Foundation of China (grant number 81370364), Innovative investigators project grant from the Health Bureau of Henan Province, Program Grant for Science \& Technology Innovation Talents in Universities of Henan Province (2012HASTIT001), and Henan provincial science and technology achievement transformation project (122102310581), Henan province of medical scientific research project (201203027), China

Received: 30 August 2014 Accepted: 20 November 2014 Published online: 12 December 2014

\section{References}

1. Holick MF: Vitamin D deficiency. N Engl J Med 2007, 357:266-281.

2. Adams JS, Hewison M: Update in Vitamin D. J Clin Endocrinol Metab 2010, 95:471-478

3. Holick MF: Vitamin D: importance in the prevention of cancers, type 1 diabetes, heart disease, and osteoporosis. Am J Clin Nutr 2004, 79:362-371.

4. Lee $P$, Nair $P$, Eisman JA, Center JR: Vitamin D deficiency in the intensive care unit: an invisible accomplice to morbidity and mortality? Intensive Care Med 2009, 35:2028-2032.
5. Lucidarme O, Messai E, Mazzoni T, Arcade M, du Cheyron D: Incidence and risk factors of vitamin $D$ deficiency in critically ill patients: results from a prospective observational study. Intensive Care Med 2010, 36:1609-1611.

6. Matthews LR, Ahmed Y, Wilson KL, Griggs DD, Danner OK: Worsening severity of vitamin $D$ deficiency is associated with increased length of stay, surgical intensive care unit cost, and mortality rate in surgical intensive care unit patients. Am J Surg 2012, 204:37-43.

7. McKinney JD, Bailey BA, Garrett LH, Peiris P, Manning T, Peiris AN: Relationship between vitamin D status and ICU outcomes in veterans. J Am Med Dir Assoc 2011, 12:208-211.

8. Venkatram S, Chilimuri S, Adrish M, Salako A, Patel M, Diaz-Fuentes G: Vitamin $D$ deficiency is associated with mortality in the medical intensive care unit. Crit Care 2011, 15:R292.

9. Peiris AN, Bailey BA, Manning T: The relationship of vitamin D deficiency to health care costs in veterans. Mil Med 2008, 173:1214-1218.

10. Ralph R, Peter JV, Chrispal A, Zachariah A, Dian J, Sebastian T, Venkatesh B, Thomas K: Supraphysiological 25-hydroxy vitamin D3 level at admission is associated with illness severity and mortality in critically ill patients. J Bone Miner Metab 2014, DOI 10.1007/s00774-014-0585-7.

11. Rajasekhar A, Lottenberg R, Lottenberg L, Liu H, Ang D: Pulmonary embolism prophylaxis with inferior vena cava filters in trauma patients: a systematic review using the meta-analysis of observational studies in epidemiology (MOOSE) guidelines. J Thromb Thrombolysis 2011, 32:40-46.

12. Wells GA SB, O'Connell D, Peterson J, Welch V, Losos M, Tugwell P: The Newcastle-Ottawa Scale (NOS) for assessing the quality of nonrandomised studies in meta- analyses. [www.ohri.ca/programs/ clinical_epidemiology/oxford.asp] (accessed 2014 October 16).

13. DerSimonian R, Laird N: Meta-analysis in clinical trials. Control Clin Trials 1986, 7:177-188.

14. Higgins JP, Thompson SG, Deeks JJ, Altman DG: Measuring inconsistency in meta-analyses. BMJ 2003, 327:557-560.

15. Begg CB, Mazumdar M: Operating characteristics of a rank correlation test for publication bias. Biometrics 1994, 50:1088-1101.

16. Egger M, Davey SG, Schneider M, Minder C: Bias in meta-analysis detected by a simple, graphical test. BMJ 1997, 315:629-634.

17. Braun A, Chang D, Mahadevappa K, Gibbons FK, Liu Y, Giovannucci E, Christopher KB: Association of low serum 25-hydroxyvitamin D levels and mortality in the critically ill*. Crit Care Med 2011, 39:671-677.

18. Hu J, Luo Z, Zhao X, Chen Q, Chen Z, Qin H, Qin Y, Liang X, Suo Y: Changes in the calcium-parathyroid hormone-vitamin $D$ axis and prognosis for critically ill patients: a prospective observational study. PLoS One 2013, 8:e75441.

19. Aygencel G, Turkoglu M, Tuncel AF, Candır BA, Bildacı YD, Pasaoglu H: Is vitamin D insufficiency associated with mortality of critically ill patients? Crit Care Res Pract 2013, 2013:1-9.

20. Higgins DM, Wischmeyer PE, Queensland KM, Sillau SH, Sufit AJ, Heyland DK: Relationship of vitamin D deficiency to clinical outcomes in critically ill patients. Jpen-Parenter Enter 2012, 36:713-720.

21. Nair $P$, Lee $P$, Reynolds C, Nguyen ND, Myburgh J, Eisman JA, Center JR: Significant perturbation of vitamin D-parathyroid-calcium axis and adverse clinical outcomes in critically ill patients. Intens Care Med 2013, 39:267-274

22. Amrein K, Zajic P, Schnedl C, Waltensdorfer A, Fruhwald S, Holl A, Purkart T, Wunsch G, Valentin T, Grisold A, Stojakovic T, Amrein S, Pieber TR, Dobnig H: Vitamin D status and its association with season, hospital and sepsis mortality in critical illness. Crit Care 2014, 18:R47.

23. Arnson $Y$, Amital $H$, Shoenfeld $Y$ : Vitamin D and autoimmunity: new aetiological and therapeutic considerations. Ann Rheum Dis 2007, 66:1137-1142.

24. Durr UH, Sudheendra US, Ramamoorthy A: LL-37, the only human member of the cathelicidin family of antimicrobial peptides. Biochim Biophys Acta 2006, 1758:1408-1425.

25. Wang TT, Nestel FP, Bourdeau V, Nagai Y, Wang Q, Liao J, Tavera-Mendoza L, Lin R, Hanrahan JW, Mader S, White JH: Cutting edge: 1,25-dihydroxyvitamin D3 is a direct inducer of antimicrobial peptide gene expression. J Immunol 2004, 173:2909-2912.

26. Liu PT, Stenger S, Tang DH, Modlin RL: Cutting edge: vitamin D-mediated human antimicrobial activity against Mycobacterium tuberculosis is dependent on the induction of cathelicidin. J Immunol 2007 , 179:2060-2063. 
27. Mahon BD, Wittke A, Weaver V, Cantorna MT: The targets of vitamin D depend on the differentiation and activation status of CD4 positive T cells. J Cell Biochem 2003, 89:922-932.

28. Heine G, Anton K, Henz BM, Worm M: 1alpha,25-dihydroxyvitamin D3 inhibits anti-CD40 plus IL-4-mediated IgE production in vitro. Eur J Immunol 2002, 32:3395-3404.

29. Adorini L, Penna G, Giarratana N, Roncari A, Amuchastegui S, Daniel KC, Uskokovic M: Dendritic cells as key targets for immunomodulation by Vitamin D receptor ligands. J Steroid Biochem Mol Biol 2004, 89-90:437-441.

30. Deluca HF, Cantorna MT: Vitamin D: its role and uses in immunology. FASEB J 2001, 15:2579-2585.

31. Mora JR, Iwata M, von Andrian UH: Vitamin effects on the immune system: vitamins A and D take centre stage. Nat Rev Immunol 2008, 8:685-698.

32. Kankova M, Luini W, Pedrazzoni M, Riganti F, Sironi M, Bottazzi B, Mantovani A, Vecchi A: Impairment of cytokine production in mice fed a vitamin D3-deficient diet. Immunology 1991, 73:466-471.

33. Baeke F, Takiishi T, Korf H, Gysemans C, Mathieu C: Vitamin D: modulator of the immune system. Curr Opin Pharmacol 2010, 10:482-496.

34. Baeke F, Gysemans C, Korf H, Mathieu C: Vitamin D insufficiency: implications for the immune system. Pediatr Nephrol 2010, 25:1597-1606.

35. Hewison M: Vitamin D and the immune system: new perspectives on an old theme. Endocrinol Metab Clin North Am 2010, 39:365-379.

36. Lee P: Vitamin D metabolism and deficiency in critical illness. Best Pract Res Clin Endocrinol Metab 2011, 25:769-781.

37. Nylen ES, Alarifi AA: Humoral markers of severity and prognosis of critical illness. Best Pract Res Clin Endocrinol Metab 2001, 15:553-573.

38. Amrein K, Schnedl C, Holl A, Riedl R, Christopher KB, Pachler C, Urbanic PT, Waltensdorfer A, Munch A, Warnkross H, Stojakovic T, Bisping E, Toller W, Smolle KH, Berghold A, Pieber TR, Dobnig H: Effect of high-dose vitamin D3 on hospital length of stay in critically ill patients with vitamin $D$ deficiency: the VITdAL-ICU Randomized Clinical Trial. JAMA 2014, 312:1520-1530.

39. Roth HJ, Schmidt-Gayk H, Weber H, Niederau C: Accuracy and clinical implications of seven 25-hydroxyvitamin D methods compared with liquid chromatography-tandem mass spectrometry as a reference. Ann Clin Biochem 2008, 45:153-159.

doi:10.1186/s13054-014-0684-9

Cite this article as: Zhang et al: Association between vitamin D deficiency and mortality in critically ill adult patients: a meta-analysis of cohort studies. Critical Care 2014 18:684.

\section{Submit your next manuscript to BioMed Central and take full advantage of:}

- Convenient online submission

- Thorough peer review

- No space constraints or color figure charges

- Immediate publication on acceptance

- Inclusion in PubMed, CAS, Scopus and Google Scholar

- Research which is freely available for redistribution 